\title{
Development of Electronic Book (E-Book) EPUB-Based for Display Course
}

\author{
Oktafiany Widhi Astuti \\ Djoko Dwi Kusumajanto \\ Program Studi Pendidikan Tata Niaga, Universitas Negeri Malang \\ Email: djoko.dwi.kusumajanto.fe@.um.ac.id
}

\begin{abstract}
The aim of this research is to produce a source of learning in the form of electronic book (e-book) with EPUB format for the Product Management Subject, and measuring the effectiveness of the use of e-book as a source for student learning independently. The study was conducted using the development model proposed by Sugiyono. This study used a questionnaire to obtain data validated by an expert. Students are as audience in learning using e-book based EPUB. The average of validation result and trial of effectiveness of EPUB-based e-book used calculation of joint validity which resulted percentage of $86,14 \%$ which means very valid and suitable to be used as alternative learning source for the Product Management Subject.
\end{abstract}

Keywords : e-book development, EPUB, Product Management

One of marketing job scope which need specialization and deep and structured analysis skill is display competency. Display is a way to push attention and consumer wants in shop or goods and push willingness to buy through direct visual appeal. Development and better facility in display, able to make as chance to do trading business, especially retail. Ability for display will give advantage to dominate in retail industry. Importance of display skill need concentrating in training program also learning in class (Din, et al., 2016)

One of training which able to get in academic field is education institute which is school. Sekolah Menengah Kejuruan (SMK) is institutions which in the inside contribute in education implementation and training several programs which tailored with work field needs. Those specializations grouped by industrial or profession group in Kurikulum Tingkat Satuan Pendidikan (KTSP). Learning approach in KTSP based on learning competency based. Display is one of marketing program competency which have to mastered and as part of learning serial of other competencies. Display standard competency is in first place, so students have to learn seriously and no requirement which have to study another standard competency first. Competency standard of display consist of three basic components are interpreting product placing visual planning, product display, and keep product display so still with company standard and planning.

In learning activity in SMKN 2 Kediri, teacher only one of several study sources which able to help student study. Development of science and technology pushing update effort in study process. Teachers demanded able to use tools which follow development of age and able to develop skills in making learning media 
which will use. Interview result with display course teacher shows that module or book development is needed because student have been needed learning media which follow technology development.

This condition isn't effective enough, while in display course teacher train student skillful in product display for pushing willingness to buy through direct visual appeal, for good learning also need visual education (Paed, et al., 2012; Jerabel, et al., 2014). It looks attractive with text, picture, audio, and video in a source also study media so student able to understand and prepare early about placing a product in field. Those problem gives idea for researcher to develop electronic book which help student in order to understand material and as student's study sources which related to visual education with using computer laboratory marketing major and personal devices which student had. Oetomo (2005) said that electronic book is a technology breakthrough, which through electronic devices with pocket book size, user able to access material books, fiction, dictionary, encyclopedia, making personal note, and save file. Based on Wikipedia electronic book is electronic version of book which contain digital information with several popular electronic book formats, such as text, pdf. Jpeg, doc lit, and html. EPUB is open standard file format for digital book which developed by International Digital Publishing Forum (IDFF) in October 2011. One of main function of EPUB format for reader is this format makes text book automatically adjust to several screen size, such as for smartphone, netbook, and eReader device.

This electronic book will be designed to help student in order to understand material and student study sources individually. This electronic book EPUB-based provide formative exercise to add knowledge and train student's creativity with several tasks about display implementation and display application. Based on learning approach KYSP is complete learning (Sutrisno \& Ruswadi, 2010; Guskey, 2015; Amiruddin et al., 2015). Understand attitude, knowledge, and skill so able to work in line with their profession.

\section{METHOD}

This research using Research and Development (R\&D) method which based on Borg and Gall model (in Sugiyono 2014). Based on research and development steps which developed by Borg and Gall (in Sugiyono 2014), in this research simplified into 9 steps until product revision. For tenth step, didn't do because with ninth step is enough to show effectivity of electronic book. Steps in this research can see in figure below: 


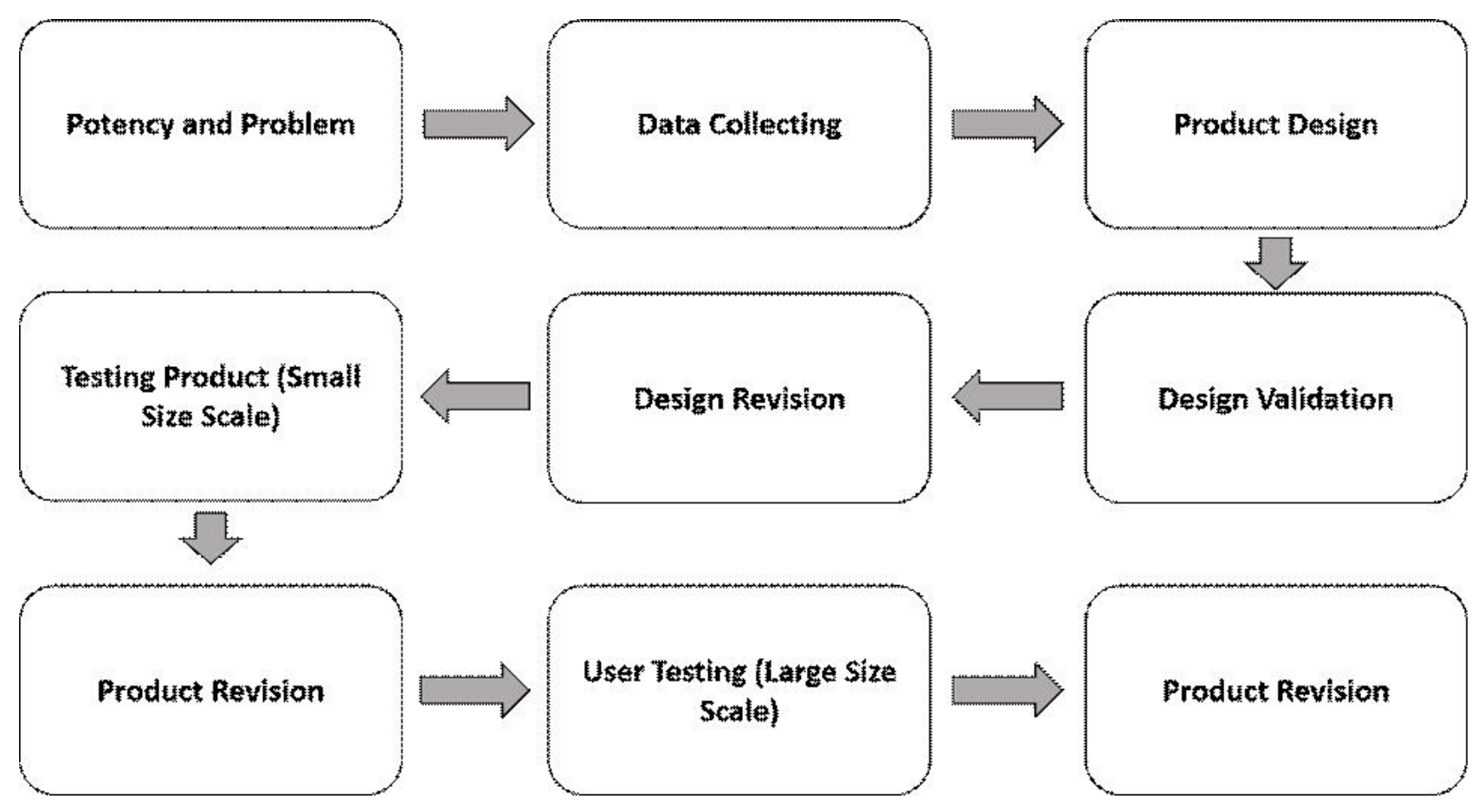

Figure 1. Steps of Using Research \& Development Method

Source: Sugiyono, 2014:298

This research done at SMKN 2 Kediri in XI grade marketing class. Electronic book design EPUB-based, researcher make design as concept map with study material expert is Dra. Siti Aeniyah, product display course teacher. Electronic book structure using Storyboard and validated by media expert with S2-Education Technology qualification, Faculty of Education in Universitas Negeri Malang. Next step after material and media validated by expert, student as product testing subject in initial stage with closed group 10 students. Testing user done after researcher revise result of product testing in small size scale, next doing use testing stage in large size scale in XI grade marketing I is 37 students. Researcher always revise how product performance, in this case is electronic book EPUBbased so able to use for refinement product.

Data which collected in this research is qualitative data from observation result, interview, critics, and suggestions in questionnaire which gave to expert and student. Qualitative data which got from questionnaire to get testing result toward product effectivity is electronic book which made by researcher. 


\section{RESULT \& DISCUSSION}

\section{Result}

Book development which done by researcher producing electronic book in EPUB format for Product Display course in basic competency product monitoring. File in EPUB format able to load text, pictures, animation, audio, video, voice over, and video. This electronic book developed using software sigil, format factory, and Readium. Software which able to use to open and read electronic book EPUB-based such as computer using EPUB reader apps is Readium (Add-on Google Chrome) and for android handheld devices with minimal version 4.2 (jelly bean) using EPUB reader apps is Ideal Group Reader (Add-on Play Store).

Result of electronic book development EPUB-based which made will explained as: (1) Bab I introduction contains: e-book product display description, requirement, direction, objective, and competency; (2) Bab II learning contains: material which made into two learning activity, objective of learning activity, material description, material resume, and multiple choice exercise; (3) Bab III evaluation contains: evaluation or exercise which made into three are cognitive skill, attitude skill, and psychomotor skill; (4) Reference list and writer biographic.

Electronic book EPUB-based for Product Display course in basic competency monitoring product validated by study material expert with score as $90 \%$ presented in figure below:

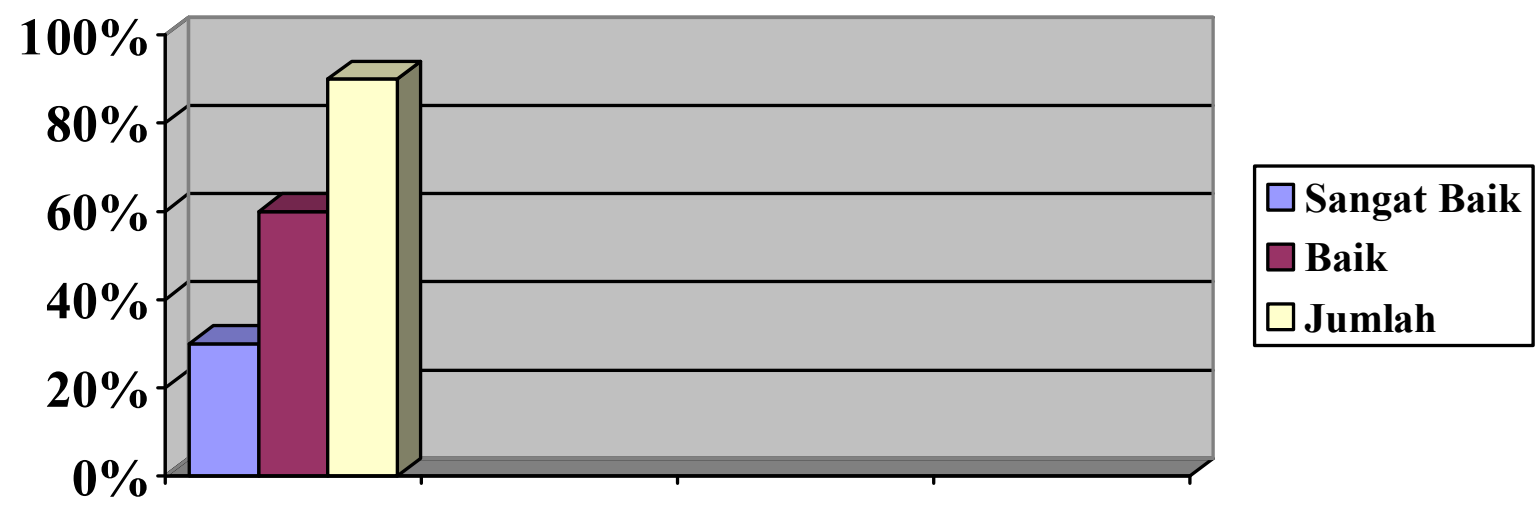

Figure 2. Study Material Expert Validations Result

Critics and suggestions which given by study material expert is material still globally, so material make clearer and more understandable by adding illustration and concrete picture. Study material validations which chosen to measure media validity is Faculty of Education lecture. Universitas Negeri Malang which experienced in media field is Yerry Soepriyanto with score as $88.66 \%$ presented in figure below: 


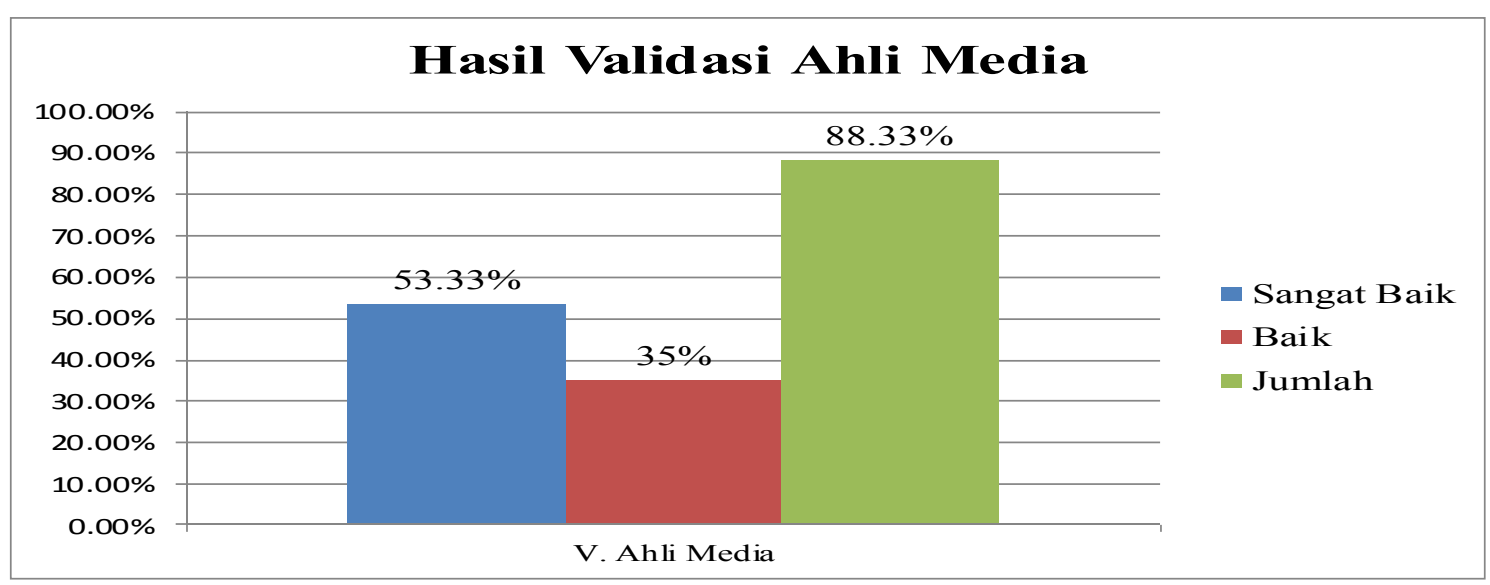

Figure 3. Media Expert Validations Result

Critics and suggestion which given by media expert is steps of installation need to clarify, setting 1 page containing not complete font, better present in continuous layout. Based on figure 1 and 2 able to conclude that electronic book EPUB-based get effectivity criteria validity very valid, so it feasible to tested in small size scale which is contain $10 \mathrm{XI}$ grade marketing students with score as $82 \%$. Critics and suggestions which given is font size in electronic book didn't big enough and suggestion to add audio to entertain while reading. After small size testing result, which done by researcher, revise product first, then doing use testing in learning activity by user which is product display teacher and audience in learning activity using electronic book EPUB-based which is XI grade marketing student with get score which presented in figure below:

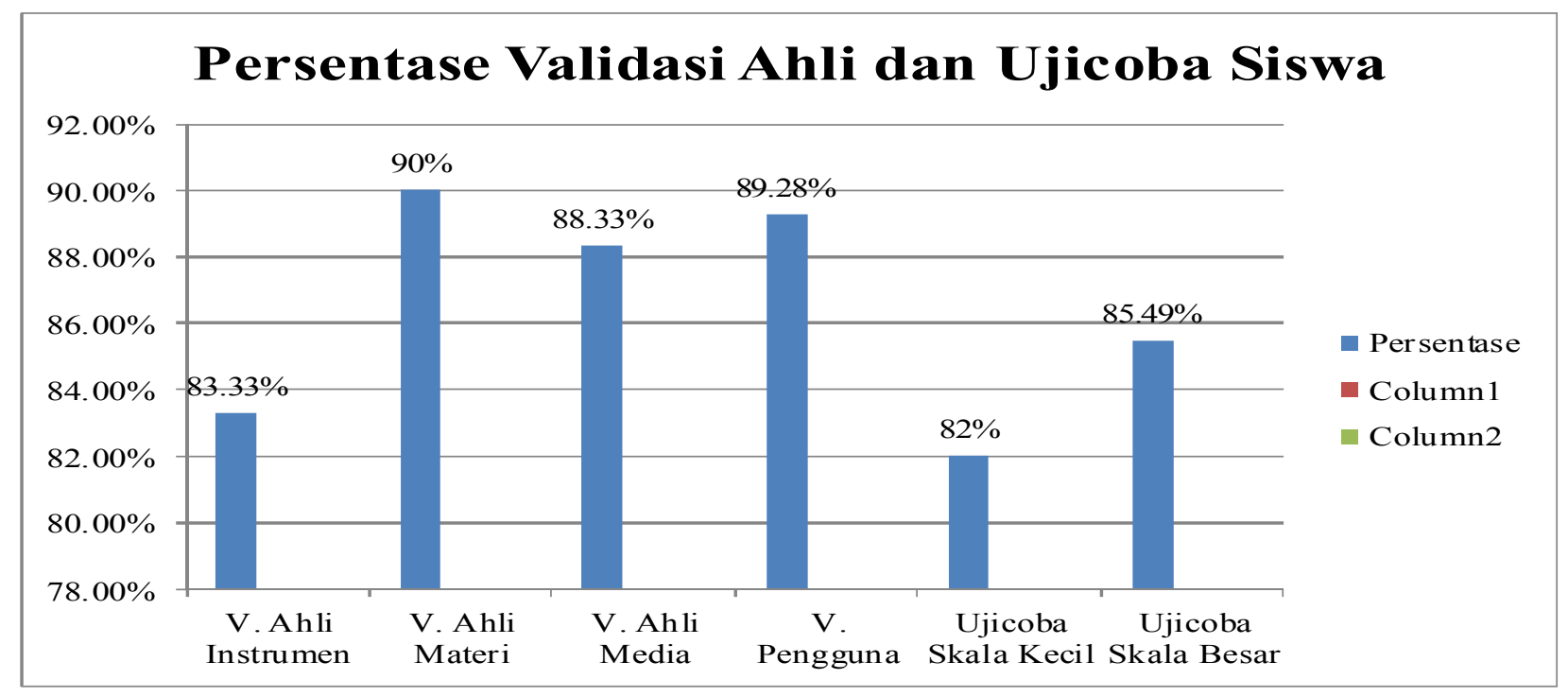

Figure 4. Expert Validation and Student Testing Result

Those figure shows that electronic book EPUB-based is very valid and feasible to become alternative study sources, especially for product display course for students individually and in line with teacher's hope that students need 
learning sources which follow development with using facilities which school have also private devices which student have.

\section{Discussion}

Book development which done by researcher is producing electronic book in EPUB format $\mathrm{CD}$, which is Product Display in basic competency of product monitoring. EPUB format is format which used for e-book, not for printing. EPUB is format which designed to read with computer devices also handheld devices such as android. Font size and paragraph settings in EPUB format which adjusting with screen size, so simple and comfort for read books digitally. This electronic book development is developed using programming language with HTML, CSS, and Java Script. Viewporter as software for making electronic book EPUB-based and Readium as reader software od electronic book using computer devices or laptop. Materials which presented in electronic book EPUB-based is tailored with Curriculum Tingkat Satuan Pendidikan (KTSP) which use in SMKN 2 Kediri with using complete learning system which is not only learning materials which written in books, but also train knowledge, attitude, and students skill in learning activity.

\section{CONCLUSION \& SUGGESTION}

\section{Conclusion}

Based on product review which developed by researcher, there are several conclusions which explain next: 1) Development result in this research is electronic book EPUB-based for Display course in Product Display basic competence for XI grade marketing in SMKNn2 Kediri; 2) Result of electronic book validation by expert and students able to conclude that with using mix validity get percentage as $86.41 \%$ is very valid criteria, so electronic book which developed by researcher feasible to use as an alternative study sources in learning activity in class also used by students individually outside class; 3) Student responds while using electronic book EPUB-based in learning activity shows that they are helped with study sources which electronic based, because easy to get and used in learning activity also outside learning activity individually using their own personal device.

\section{Suggestion}

Suggestions for school, have to provide multimedia facilities which sufficient, such as hotspot area, computer laboratory, and school website for easy access and book distribution. Suggestion for teacher, able to use as one of electronic media by MGMP for producing media and learning sources for all students in Kediri. Suggestion for students, who don't have laptop also can use android with minimal 
version 4.2 (jelly bean) for using electronic book EPUB-based as one of study source individually. Suggestion for further researcher to searching applications references EPUB readers, if in PC didn't available browser except Google Chrome.

\section{REFERENCES}

Akbar,S. (2013). Instrumen Perangkat Pembelajaran. Bandung: Remaja Rosdakarya.

Amiruddin, dkk. (2015). An Investigation Effects of Mastery Learning Strategy on Enterpreneurship Knowledge Acquisition among Aboriginal Students. EJournal ScienceDirect, Vol.204: 183-190. (Online), (http://www.sciencedirect.com/science/article/pii/S1877042815047795), diakses pada 10 Mei 2017

Arsyad, A. (2013). Media Pembelajaran. Jakarta: Raja Grafindo Persada.

Bartalesi, S \& Lemporini, B. (2013). Investigating an Accessible and Usable ePub Book via VoiceOver: A Case Study. (Online), (http://link.springer.com/chapter/10.1007/978-3-642-39062-3 17), diakses pada 20 Desember 2016

Bartalesi, S \& Lemporini, B. (2015). An Enrich ePub eBook for Screen Reader Users. (Online), (http://link.springer.com/chapter/10.1007/978-3-20678-3 36), diakses pada 8 November 2016.

Din, dkk. (2016). The Effectiveness of the Enterpreneurship Education Program in Upgrading Enterpreneurial Skill among Public University Students. E-Journal ScienceDirect, Vol.224: 117-123. (Online), (http://www.sciencedirect.com/science/article/pii/S1877042816304979), diakses pada 10 Mei 2017

Guskey, T.R. (2015). International Encyclopedia of the Social \& Behavioral Science (Second Edition). E-Journal ScienceDirect, Pages: 752-759. (Online), (http://www.sciencedirect.com/science/article/pii/B9780080970868260 39X), diakses pada 10 Mei 2017

International Digital Publishing Forum. 2017. EPUB. (Online), (http://idpf.org/epub), diskes pada 10 Mei 2017

Jerabek, T. Rambbousek, V. Wildova, R. (2014). Specifics of Visual Perception of the Augmented Reality in the Context of Education. E-Journal ScienceDirect, Vol.159: 598-604.

(Online), (http://www.sciencedirect.com/science/article/pii/S1877042814065628), diakses pada 10 Mei 2017

Martutik \& Rani, Abdul. 2012. Menulis Dasar Berbasis Tugas. Malang: Surya Pena Gemilang. 
Oetomo, B.2005 . e-Education Konsep, Teknologi, dan Aplikasi Internet Pendidikan. Yogyakarta: Andi.

Paed, dkk. (2012). Improvement in Education of People with Visual Impairment. EJournal ScienceDirect, (55) 971-979. (Online), (http://www.sciencedirect.com/science/article/pii/S1877042812040499), diakses pada 10 Mei 2017

Puspitasari, D. 2008. BSE Penjualan Jilid 3 untuk SMK. Jakarta: Direktorat Pembinaan Sekolah Menengah Kejuruan, Direktorat Jenderal Manajemen Pendidikan Dasar dan Menengah, dan Departmen Pendidikan Nasional.

Sugiyono. 2014. Metode Penelitian Kuantitatif, Kualitatif dan R\&D. Bandung: Alfabeta.

Sutrisno, Ruswandi. 2010. Modul Menata Produk. Sukabumi :Yudistira.

Widaningsih \& Samsul,R. 2012. Menata Produk untuk SMK dan MAK. Jakarta: Erlangga. 